1032

INCREASED CEREBRAL METABOLIC RATE AND DECREASED ANOXIC SURVIVAL AFTER AMINOPHYLLINE IN YOUNG MICE. Jean Holowach Thurston, Richard E. Hauhart, and John A. Dirgo. Dept. Pediat., Wash. Last year we reported that in $17-21$ deld of cyclic AMP $56 \%$ $(p=0.01)$, cyclic GMP $36 \%(p=0.01)$, glucose $93 \%(p<0.001)$, ADP $12 \%(p=0.04)$, and AMP $70 \%(p=0.02)$. ATP, P-creatine, glycogen and lactate were unchanged. Increased ADP and AMP levels are sensitive indicators of ATP ( $\sim$ P) breakdown and sugges an increased cerebral metabolic rate (CMR). To test this hypothesis, the effect of AP ( $100 \mathrm{mg} / \mathrm{kg} \mathrm{i.p.)} \mathrm{on} \mathrm{CMR} \mathrm{was} \mathrm{determined}$ in 48 weanling mice (Lowry et al, J. Biol. Chem. 239:18, 1964).
AP increased CMR 3-fold $-34 \mathrm{mmol} / \mathrm{kg} / \mathrm{min} \sim \mathrm{P}(1.03 \mathrm{mmol} / \mathrm{kg} / \mathrm{min}$ glucose) vs $12 \mathrm{mmol} / \mathrm{kg} / \mathrm{min} \sim \mathrm{P}(0.36 \mathrm{mmol} / \mathrm{kg} / \mathrm{min}$ glucose $)$ in controls. Increased CMR is accompanied by increased extraction of glucose from blood and could explain the brain glucose elevation. Incos neuronal function, this may be the mechanism by which AP restores normal breathing this may be the mechanism by which AP restores normal breathing in premature babies with apnea. However, with a decreased glucose and/or $0_{2}$ supply to brain, increased CMR would be a dist treated with a therapeutic dose of AP $(7.5 \mathrm{mg} / \mathrm{kg}$ s.c.). Fifteen to $60 \mathrm{~min}$ after injection, one control and one AP-treated littermate were exposed to $\mathrm{N}_{2}$ gas for varlable intervals. Survival rate of 32 mice was $62 \%$ for controls vs $0 \%$ in AP-treated animals. of 32 mice was $62 \%$ for controls vs anoxic newborns.

\title{
IONIZED Ca (iCa) IN RELATION TO GESTATIONAL AGE
}

1033 Reginald C. Tsang, Lori Abrams, Thomas H. Joyce

Previous studies of serum $\mathrm{Ca}$ in relation to gestational age have not examined $\mathrm{iCa}$, the physiologically active fraction of circulating $\mathrm{Ca}$. Forty-three infants with birth weights appropriate for gestational age were studied from birth to $72 \mathrm{hrs}$. of age Ionized Ca was determined by the Orion 99-20 flow-thru electrode standardized with aqueous and serum standards. Normal serum iCa in 35 young adults ranged from 3.6 to $4.5 \mathrm{mg} / \mathrm{dl}$; in 34 well full term infants on day 3 , iCa ranged from 3 to $4 \mathrm{mg} / \mathrm{d} 1$. Fifteen of $43(35 \%)$ of study infants were "hypocalcemic" (serum iCa $\leq 3 \mathrm{mg} / \mathrm{dl}$ ) on at least one occassion in the first 3 days of life. Serum iCa levels were correlated with total Ca levels (correlation $\mathrm{r}=0.588, \mathrm{p}<.001)$. At birth, umbilical venous serum $\mathrm{iCa}$ was correlated with simultaneous maternal 1Ca $(r=0.658, p<0.01)$, but significantly higher than maternal values $(4.7 \pm .11 \mathrm{mg} / \mathrm{d} 1$

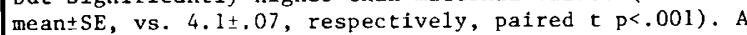
greater decrease of serum iCa from birth to $24-48 \mathrm{hrs}$. was related to a higher cord blood iCa $(r=0.611, p<.011)$. Serum ica at $24 \mathrm{hrs}$ correlated with gestational age $(\mathrm{r}=0.43, \mathrm{p}<.05)$ and the amount of bicarbonate received $/ \mathrm{kg}$ body weight/first 24 hrs. ( $r=.527, p<.01)$ but not with birth weight $(r=.210)$. Serum iCa at 24 hours was related to serum iCa at 48 and $72 \mathrm{hrs}$ $(r=.794,0709)$. Thus, serum iCa at birth is correlated with, but higher than simultaneous maternal iCa; serum 1Ca at $24 \mathrm{hrs}$. of age is significantly correlated with gestational age.

1034 GLUCOSE INTOLERANCE IN VERY LOW BIRTHWEIGHT (VLBW) 34 INFANTS. Yvonne E. Vaucher and Grant Morrow III, Dept The frequency of glucose intolerance (blood glucose or Dextrostix $\geq 130 \mathrm{mg} \%$ for $\geq 12$ hours accompanied by giucosuria $\geq \mathrm{tr}$ ) was determined in 30 consecutively born (IV) glucose (glu). The majority, $87 \%(26 / 30)$, survived.

Twenty episodes of glucose intolerance occurred in $14(47 \%)$ of the infants. Day of onset varied widely $(\bar{x}=8$, range $0-25)$ as did duration $(\dot{\bar{x}}=4$, range $0.5-9.0)$. Intolerant infants were smaller $(0.98$ vs $1.10 \mathrm{~kg} p<.01)$; more premature $(28.5$ vs 30.2 weeks gestation, $\mathrm{p}<.01$ ); more of ten had respiratory failure (90 vs $50 \%$ ) and hyperglycemia (62 vs $33 \%$ ) within the first 24 hours; and were fed orally later (da 13 vs da $5, p<.001$ ) than infants who did not become intolerant.

Clinical events known to be associated with hyperglycemia preceded $1 / 3$ of the ep 1 sodes. The remainder were associated only with an increase $(\bar{x}=0.2 \mathrm{~g} / \mathrm{kg} / \mathrm{h})$ in IV glu infusion rate. Only 3 eplsodes resolved without reducing the IV glu load. Eleven ep sodes $(55 \%)$ required a decrease $(\bar{x}=0.5 \mathrm{~g} / \mathrm{kg} / \mathrm{h})$ in glu infusion rates to less than that $(\bar{x}=-0.3 \mathrm{~g} / \mathrm{kg} / \mathrm{h})$ tolerated prior to hyp glycemia and resulted in a $40 \%$ decrease in caloric intake.

These data suggest that glucose intolerance, a common problem in the nutritional management of VLBW infants, is usually due to an increase in IV glu load alone; that early oral feeding may reduce the risk of occurrence; and that glu tolerance frequently deteriorates following persistent hyperglycemia and glucosuria.

1035

SKIN OXYGEN PERMEABILITY IN PREMATURE INFANTS. Han T. Versmold, Mathaeus Holzmann, Otwin Linderkamp, Klaus P. Riege1 (spon. William H. Tooley) Divisio

Neonatology, Dept. of Pediatrics, Univ. Munich, W. Germany.

Human skin is permeable to $\mathrm{O}_{2}$ but the $\mathrm{Po}_{2}$ on the unheated in tact skin is below 3.5 torr in adults and below 7 torr in term infants, both during air and $\mathrm{O}_{2}$ breathing. In small pren

We measured the Po2 on the nonheated skin surface with an unWe measured the $\mathrm{PO} 2$ on the nonheated skin surface with an unwks) at various $\mathrm{F}_{1} \mathrm{O}_{2}$ levels. The infants were studied in a thermoneutral environment at age $2-48 \mathrm{hrs}$. When the arterial $\mathrm{O}_{2}$ tension $\left(\mathrm{PaO}_{2}\right)$ was $50-100$ torr the mean surface $\mathrm{Po}_{2}$ of unheated skin was 27.2 (range 19-38) torr in infants $<1500 \mathrm{~g}, 14.3(4-23)$ torr and those of $1500-2500 \mathrm{~g}$ and $2.9(2.5-5.0)$ torr in infants $>2500 \mathrm{~g}$. Skin temperatures were not different between these $>2500 \mathrm{~g}$. Skin temperatures were not different between these
groups. In contrast to adults and term infants, in infants $<1500 \mathrm{~g}$ the skin surface $\mathrm{Po}_{2}$ correlated with the $\mathrm{PaO}_{2}$ up to 100 torr ("unheated" skin $\mathrm{Po}_{2}=0.33 \mathrm{PaO}_{2}+5.42 ; \mathrm{r}=0.76$ ). Crying, blood transfusion and phototherapy markedly increase the skin $\mathrm{Po}_{2}$ suggesting that a higher skin blood flow contributes more than differences in skin diffusion resistance or metabolism to the higher skin surface $\mathrm{Po}_{2}$ in resting premature babies.

The concept of the unheated skin as a virtually oxygen tight system obviously has to be revised for premature infants. Practical implications however, must remain a matter of speculation since oxygen fluxes across the unheated skin have not been measured in small premature infants. Supported by
Deutsche Forschungsgemeinschaft (SFB $147^{\circ}$ and Ve $32 / 3$ ).

1036 A NEW DEVICE FOR DIAGNOSIS AND EVACUATION OF NEONATAI
PNEUMOTHORACES. Marcia J. Wagaman, John G. Shutack, Ara S. Moomjian, Ronald D. Eavey, Thomas H. Shaffer, William W. Fox. (Spon. by Jean A. Cortner), Univ. of Pa. Sch. Of Med., Dept. of Peds., The Children's Hospital of Philadelphia, A closed system (CS) device with teflon needle, sideholes, and attached stopcock was compared to a Medicut needle to determine incidence of unintentional introduction of air during diagnosis, and efficiency of evacuation of neonatal pneumothoraces (PTX).

Thoracentesis was evaluated in 10 white rabbits $(1.3-1.6 \mathrm{~kg}$ ) with the CS needle in $R$ chest and Medicut in L chest. Evacuation of free intrapleural air following thoracentesis and evacuation of intentionally injected air $(20 \mathrm{cc})$ was performed on both sides of the chest. Intrapleural pressure measurements, $x$-rays, and number ml. air evacuated were used to quantitate each step. The CS heedle produced no air entry on $x$-ray and no changes $(p>0.05)$ in (mean \pm SEM) insplratory pleural pressure (IPP) $(-5.2 \pm 0.62 \mathrm{~cm}$ H20) or expiratory pleural pressure (EPP) $(-0.94 \pm 0.5 \overline{5})$. Medicut taps $(4.5 \mathrm{sec}$. to position stopcock) resulted in PTX on x-ray in $70 \%$ of trials and significant increase $(P<0.05)$ of $1.28 \pm 0.28$ $\mathrm{cm} \mathrm{H}_{2} \mathrm{O}$ in IPP and $1.58 \pm 0.36 \mathrm{~cm} \mathrm{H} 2 \mathrm{O}$ EPP from baseline values. $23.7 \mathrm{cc}$ (mean) air was evacuated from Medicut side. After $20 \mathrm{cc}$ injection of air on CS needle side, a mean of $25.0 \mathrm{cc}$ air was r moved. Complete air evacuation occurred in $90 \%$ of CS needle trials vs. $60 \%$ with Medicut. The CS needle was safer, and more fficient than Medicut in evacuating air. In addition, since it is an airtight system, the CS needle can be used for diagnosis bf PIX without the risk of introducino air.

1037 FACTORS DETERMINING THE CELLULAR UPTAKE OF BILIRUBIN. of California, Davis - Sacramento Medical Center,

Sacramento, California.

The toxicity of bilirubin is a function of the amount of bilimubin bound to cellular elements and the sensitivity of the cell to a given bilirubin load. We have examined the stoichiometry of cell binding of bilirubin by incubating red blood cells with various concentrations of bilimubin and serum in vitro, measuring the serm unbound bilirubin concentration (UBC) with the peroxidase assay, and extracting the RBC bilirubin with a human serm albumin solution.

Results: (1) The partitioning of the total bilirubin pool between serum and cells reached equilibrium within 10 minutes.

(2) At equilibrium, the cellular content of bilirubin was a function of the UBC and not the total bilirubin concentration or pilirubin/albumin molar ratio.

(3) Albumin binding of bilirubin was not affected by $\mathrm{pH}$

(4) Cellular uptake of bilirubin was greatly influenced by $\mathrm{pH}$. At physiological pH, bilimubin exists predominantly as an anion with only a small fraction present as the bilirubin acid. The increased bilirubin uptake at $\mathrm{pH} 7.0$ vs. $\mathrm{pH} 7.4$ corresponded to the calculated increase in the less soluble protonated bilirubin. Conclusions: Cellular uptake of bilirubin is a function of the concentration of free bilirubin acid. It is probable that the risk for kernicterus (with respect to blood chemistries) can pe estimated by measuring the serum UBC and blood $\mathrm{pH}$. 